\title{
Stem cells, in vitro gametogenesis and male fertility
}

\author{
Go Nagamatsu and Katsuhiko Hayashi \\ Department of Stem Cell Biology and Medicine, Graduate School of Medical Sciences, Kyushu University, \\ Fukuoka, Japan
}

Correspondence should be addressed to K Hayashi; Email: hayashik@hgs.med.kyushu-u.ac.jp

This paper is part of an Anniversary Issue celebrating 25 Years of ICSI. The Guest Editor for this section was Professor Gianpiero Palermo.

\begin{abstract}
Reconstitution in culture of biological processes, such as differentiation and organization, is a key challenge in regenerative medicine, and one in which stem cell technology plays a central role. Pluripotent stem cells and spermatogonial stem cells are useful materials for reconstitution of germ cell development in vitro, as they are capable of differentiating into gametes. Reconstitution of germ cell development, termed in vitro gametogenesis, will provide an experimental platform for a better understanding of germ cell development, as well as an alternative source of gametes for reproduction, with the potential to cure infertility. Since germ cells are the cells for 'the next generation', both the culture system and its products must be carefully evaluated. In this issue, we summarize the progress in in vitro gametogenesis, most of which has been made using mouse models, as well as the future challenges in this field.

Reproduction (2017) 154 F79-F91
\end{abstract}

\section{Introduction}

Gametes are highly specialized cells for the creation of new individuals. To finally become functional gametes, the germ cell lineage including the precursors undergoes a unique series of differentiation processes orchestrated by genetic and epigenetic regulations (McLaren \& Lawson 2005, Sasaki \& Matsui 2008). Conceptually, the process can be divided into two phases. In the first phase of differentiation, which is sex independent, the cells propagate as a founder population while erasing epigenetic memories in the genome. In the second phase of differentiation, which is sex dependent, the cells undergo remarkable morphological changes with de novo epigenetic modifications while halving the genome by meiosis. The first phase commences in primordial germ cells (PGCs) that are specified at an early stage of embryogenesis (Lawson \& Hage 1994, Ohinata et al. 2005). Once PGCs are specified, they erase $\mathrm{CpG}$ methylation and begin to reorganize histone modifications at a genome-wide level (Seki et al. 2005). PGCs migrate toward the gonad while proliferating and acquire an 'epigenetic ground state' upon settling in the gonad. The cell population is the founder for the subsequent second phase. During the first phase, there is no clear difference in gene expression and differentiation potency between males and females (Adams \& McLaren 2002, Jameson et al. 2012). In the second phase, however, differentiation becomes more complicated and interactive with surrounding somatic cells. Once entering the female gonad, PGCs enter meiosis (thereby becoming primary oocytes). At the perinatal stage, a majority of oocytes are eliminated by cell death (Pepling \& Spradling 2001, McClellan et al. 2003) and the remaining oocytes form primordial follicles that function as a storage of oocytes, ensuring the longevity of the reproductive life in the female. After puberty begins, some of the primordial follicles periodically undergo follicular development, which is characterized by proliferation of granulosa cells, maturation of theca cells and oocyte growth accompanied with de novo epigenetic modifications in the genome. When the oocyte growth reaches the plateau stage, meiosis resumes until it is arrested again at the meiotic metaphase II (MII) stage for fertilization. In the male gonad, on the other hand, PGCs are arrested at the G1 stage, and thereby become prospermatogonia. During the cell cycle arrest, the prospermatogonia acquire de novo epigenetic modifications (Davis et al. 2000, Ueda et al. 2000, Ly et al. 2015). After birth, some of the prospermatogonia become spermatogonial stem cells (SSCs), which are crucial for sustaining spermatogenesis. After puberty begins, SSCs become differentiated types of spermatogonia, followed by spermatocytes, in which meiosis takes place to form haploid spermatids. By tight interaction with Sertoli cells, mature spermatozoa with tiny heads and long tails are formed from the spermatids. 
One of the key goals in reproductive biology is to reconstitute all the processes of gametogenesis in culture, in order to produce a functional egg and sperm. Such in vitro gametogenesis will make it easy to analyze the complicated process of germ cell development. This may be particularly effective for the analysis of nascent PGCs, because the number of these cells is quite small in the embryos. In other words, in vitro gametogenesis could replace the use of experimental animals in accordance with the Animal Welfare Acts of various nations. From a more practical point of view, gametes produced by in vitro gametogenesis, termed in vitro gametes, could be an alternative source for animal reproduction, such as for the propagation of endangered animals (Saragusty et al. 2016). Moreover, once the capability for producing human in vitro gametes exists, their great potential utility will necessitate a discussion as to whether they should be used for human reproduction. Due to the unique capability of the germ cell lineage, in vitro gametogenesis has a huge impact on a wide range of research. Recent progress in mice suggests that in vitro gametes are not a fantasy, but realistically achievable materials that will promote basic research and provide a practical strategy for reproduction. These achievements are based on accumulating knowledge on developmental biology, stem cell biology and cell culture technologies. Stem cells in particular are an essential material for realizing in vitro gametogenesis, since they can propagate indefinitely under certain conditions while maintaining their ability to differentiate.

\section{Reconstitution of PGC specification in vitro}

Reconstitution of PGC specification is an initial and important step for in vitro gametogenesis. Since PGCs are the founder cell population that undergoes genomewide reprogramming, their quality would reflect the developmental competence of in vitro gametes. To briefly review PGC specification in vivo in the mouse model, PGCs arise from the proximal part of the pluripotent epiblast in response to bone morphogenetic protein
(BMP) 4 secreted from the adjacent extraembryonic ectoderm at around embryonic day (E) 6.5 (Lawson et al. 1999). During specification, a set of transcription factors, such as Blimp1/Prdm1, Prdm14 and Tfap2c, orchestrate a PGC-specific gene expression program accompanied with epigenetic reprograming represented by a reduction of $\mathrm{CpG}$ methylation, di-methylation on histone $\mathrm{H} 3$ lysine 9 (H3K9me2) and a gradual increment of tri-methylation of histone $\mathrm{H} 3$ lysine 27. A key message of PGC specification in vivo is that unique responsiveness to BMP4, termed PGC competence, is conferred temporarily in the epiblast (Ohinata et al. 2009). This clearly indicates that the pluripotent state of the epiblast is distinct from that of the inner cell mass of the blastocyst that is the origin of ESCs. Therefore, to precisely reconstitute PGC specification in vitro, it is first necessary to confer PGC competence to ESCs.

The pluripotent state is currently subdivided into two phases: the naïve and prime states. The former closely resembles the pre-implantation epiblast of the blastocyst while the latter resembles the post-implantation epiblast around gastrulation (Nichols \& Smith 2009). The two states require different sets of growth factors for their self-renewal and are interchangeable under certain culture conditions. In mice, neither of the states has PGC competence (Ying et al. 2003, Hayashi \& Surani 2009). Instead, the competence is temporarily conferred during transition from the naïve state to the primed state. When mouse ESCs are cultured with bFGF and activin $A$, which drive the primed state, PGC-like cells (PGCLCs) can be efficiently induced from cells at 2 days of culture in response to BMP4 (Fig. 1) (Hayashi et al. 2011). The gene expression profile and epigenetic status of PGCLCs are highly similar to those of PGCs in vivo. Importantly, PGCLCs are functional, as they develop into sperm and oocytes in the transplanted testes and ovaries, respectively (Hayashi et al. 2011, 2012). The semi in vitro sperm and oocytes are capable of full-term development. The offspring from the semi in vitro gametes are apparently normal, as they grew up without developmental retardation or premature death,
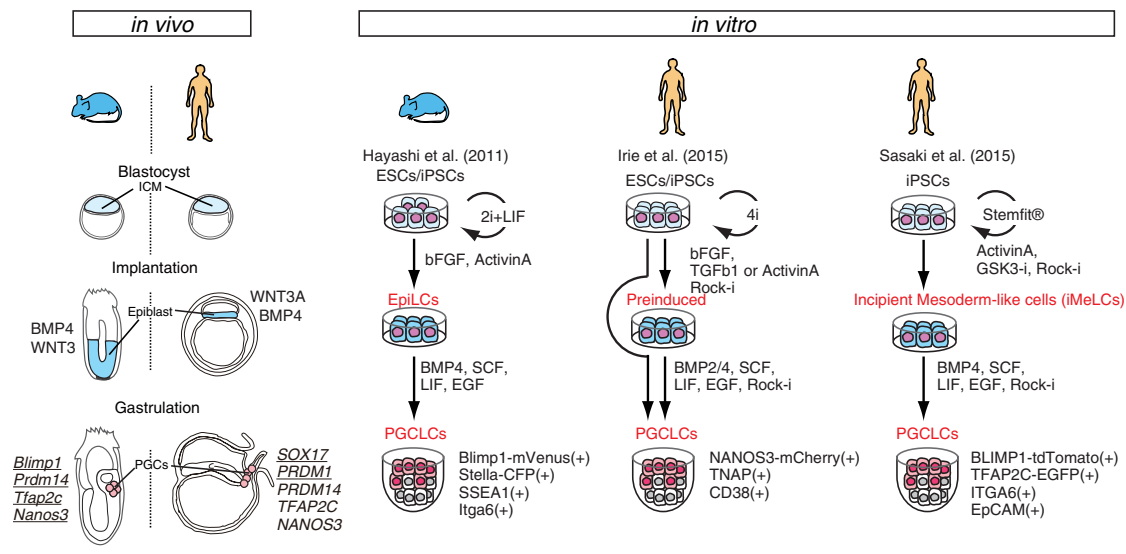

Figure 1 A conserved manner of PGC specification in vitro. PGCs are specified from the pluripotent epiblast of the postimplantation embryo in mice and humans (left: in vivo). From self-renewing ESCs/iPSCs, PGCLCs can be derived via PGC-competent cell populations (EpiLCs, Preinduced and iMeLCs). Note that cytokines for PGCLC induction are same between mice and humans. PGC marker genes are in part conserved. 
and then become fertile adults that produce normalsized litters. These studies demonstrated that the culture system successfully reconstitutes the PGC specification process. Indeed, this system has already been used to determine a set of transcription factors sufficient for PGC specification and epigenetic reprograming in nascent PGCs (Nakaki et al. 2013, Kurimoto et al. 2015), underscoring the power of in vitro gametogenesis for improving our understanding of germ cell development.

In humans, reconstitution in vitro of PGC specification has also been reported (Irie et al. 2015, Sasaki et al. 2015). As in the mouse model, the question of how best to confer PGC competence is the key issue (Fig. 1). Irie and coworkers cultured ESCs/iPSCs under $a$ ' $4 \mathrm{i}^{\prime}$ condition that included inhibitors for GSK3ß, MEK, JNK and p38 (Gafni et al. 2013, Irie et al. 2015). Human ESCs/iPSCs cultured under this condition, followed by pre-induction culture with TGF $\beta 1$ (or activin A) and bFGF, were capable of differentiating into PGCLCs in response to BMP4, SCF, LIF and EGF, which is the same as the set of cytokines used for mouse PGCLC induction. Eventually, the group found that PGCLCs could be derived directly from ESCs/iPSCs cultured under the $4 \mathrm{i}$ condition. At almost the same time, Sasaki and coworkers reported another set of culture conditions that confers PGC competence to human iPSCs: they showed that iPSCs cultured with activin A and a GSK3 $\beta$ inhibitor were transformed into incipient mesodermal cells (iMeLCs). iMeLCs efficiently differentiated into PGCLCs in response to BMP4, SCF, LIF and EGF (Sasaki et al. 2015). Irrespective of which method is used, the resulting PGCLCs have gene expression profiles and epigenetic genome modifications that are similar to those of human PGCs in vivo (Irie et al. 2015, Sasaki et al. 2015, Tang et al. 2015). Interestingly, SOX17 has a human-specific role on PGCLC specification: enforced expression of SOX17 and PRDM1/BLIMP1 at a similar level is sufficient for PGCLC specification (Kobayashi et al. 2017). This kind of experiment can be done only in an in vitro culture model, especially in humans.

\section{Reconstitution of the female germ line: oogenesis in organ culture systems}

Reconstitution of the second phase is more challenging, as the process takes a much longer time than PGC specification and proceeds in a sex-dependent manner that is in part regulated by the surrounding somatic cells. To accomplish the second-phase reconstitution, development of an organ culture system seems prerequisite. For oogenesis, there are milestone studies on organ culture systems that succeeded in the production of mature oocytes from residual precursors (Fig. 2). O'Brien and Eppig developed a two-step culture system that produces fully functional oocytes from neonatal ovaries in culture (Eppig \& O'Brien 1996, O'Brien et al. 2003). In their system, the secondary follicles were isolated from neonatal ovaries cultured for 8 days, and the secondary follicles were further cultured for an additional 14 days. Fully grown germinal vesicle (GV) oocytes were then cultured with FSH and EGF to become MII oocytes. It is of particular importance that MII oocytes developed to offspring by in vitro fertilization followed by transplantation to surrogate mothers. This culture scheme provides a prototype of in vitro oogenesis.

Partly in continuation of the prototype, Morohaku and coworkers established an organ culture system that produces mature oocytes using fetal ovaries. Notably, the system produced MII oocytes, followed by fertilized eggs, from mitotic PGCs in the fetal ovaries, thereby for the first time demonstrating the successful completion of meiosis in a female germ line in culture (Fig. 2) (Morohaku et al. 2016). Apart from the completion of meiosis, the culture system provides two important components that are requisite to achieving a robust production of oocytes in culture. The first is the prevention of multioocyte follicle (MOF) formation by inhibiting estrogenmediated signaling. In the organ culture of fetal ovaries, MOFs, which are follicles containing more than two oocytes, are frequently formed, and eventually disturb the oocyte growth in culture. Based on previous reports

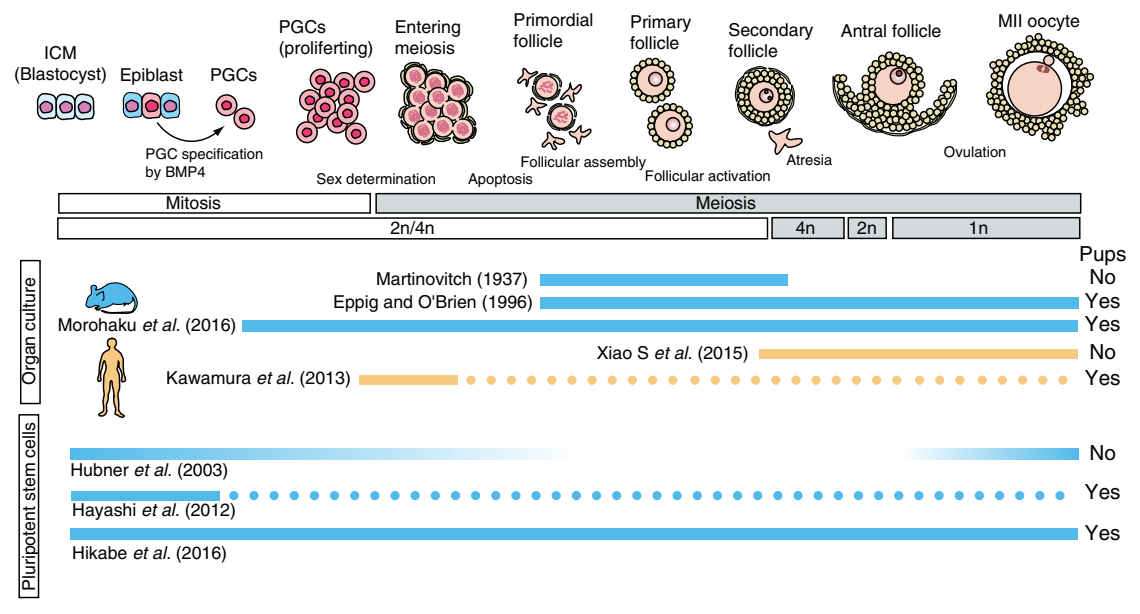

Figure 2 Summary of representative studies on in vitro oogenesis. Oogenesis is reconstituted mainly in two different ways, either organ culture or using pluripotent stem cells. Representative studies in each way are shown. The oogenic process reconstituted by each study is shown in blue (mice) or orange (humans) lines. Dashed lines indicate that the processes were bypassed by transplantation. A line fading away indicates that the process is not fully determined. 
that steroid hormones such as estrogen and progesterone trigger MOF formation (Iguchi et al. 1990, Kezele \& Skinner 2003, Lei et al. 2010, Zhang et al. 2012, Dutta et al. 2014), Morohaku and coworkers used an estrogen inhibitor, ICl182780, in their organ culture system. This dramatically prevented MOF formation and improved the yields of secondary follicles. The second crucial component is recapitulation of the follicular environment by using polyvinyl pyrrolidone (PVP). In the organ culture system, the mural follicle walls were removed by treatment with collagenase, and the remainder of the follicle structures including oocytes was cultured in medium containing PVP at $2 \%$, in which oocytes grew efficiently to fully grown GV oocytes. Although the detailed mechanism is unclear, it seems that the polymer material increases the viscosity of the medium, which may prevent diffusion of paracrine molecules (Hirao et al. 2004). This might mimic the follicular environment that is enclosed by granulosa and theca cells. The GV oocytes were then cultured in a medium containing LH and EGF. Importantly, the resultant MII oocytes from the culture were capable of fertilization and full-term development (Morohaku et al. 2016).

\section{Reconstitution of the female germ line: oogenesis from pluripotent stem cells}

Combining the technologies of the PGCLC system and the organ culture system, Hikabe and coworkers developed a culture system that produces mature oocytes from mouse ESCs/iPSCs (Fig. 2) (Hikabe et al. 2016). Because PGCLCs are arrested in a premigratory state, they need to be aggregated with somatic cells from female embryos at E12.5. The somatic cells give signal(s) that conduct PGCLCs into oogenesis. In the aggregates, which are termed reconstituted ovaries (rOvaries), the PGCLCs immediately start to express $\mathrm{MVH}$, a late PGC marker gene, and then enter meiosis. In the successful organ culture systems, the rOvaries were cultured under three different conditions - in vitro differentiation (IVDi), in vitro growth (IVG) and in vitro maturation (IVM) - in which oogenesis proceeds to primary oocytes in the secondary follicle, fully grown GV oocytes and MII oocytes, respectively. During IVDi culture, primary oocytes from ESCs/iPSCs proceeded to meiosis prophase I and eventually formed follicular structures.

Much as in the organ culture systems, individual secondary follicles were isolated and then treated with collagenase to expose the inside of the follicle structure to the medium. Under the IVG condition, the granulosa cells proliferated and oocytes simultaneously grew up. Cumulus-oocyte complexes (COCs) were eventually lifted up onto the bottom of the culture device, and exhibited a morphology resembling that of antral follicles. Oocytes in the COCs resumed meiosis and then became MII oocytes with a first polar body in IVM culture. The gene expression dynamics during oocyte differentiation in culture was largely similar to that in vivo. Importantly, ESC/iPSC-derived MII oocytes were capable of fertilization and full-term development. However, pups were produced with 20-fold lower efficiency from ESC-derived eggs than from eggs in vivo, suggesting that the quality of oocytes is at least partly compromised. Further refinement of the culture conditions will be required to improve the quality of oocytes produced in vitro. Nevertheless, since gene modification can be easily done in ESCs/iPSCs, this culture system is expected to accelerate research into gene functions in oogenesis. Moreover, it may prove to be an alternative source of eggs in mice.

\section{Reconstitution of the male germ line: organ culture of the testis to produce mature sperm}

There are several fragments of reconstitution of the male germ line. This is due to the more complicated steps in spermatogenesis-which typically include self-renewal of SSCs-compared to the corresponding steps in the female germ line. Partly for this reason, successful production of mature sperm from ESCs/iPSCs in culture has been not achieved in the male germ line as it has in the female one. Instead, a number of partial reconstitutions of spermatogenesis have been reported (Fig. 3).

The development of an organ culture system is the first step in the production of mature sperm in culture. Studies on such an organ culture system have been made for a century (Fig. 3) (Champy 1920). In 1937, Martinovitch cultured newborn testicular tissue on a blood clot and observed the progression to pachytene spermatocytes (Martinovitch 1937). Subsequently, in the 1960s, several research groups made extensive efforts to develop organ culture methods in rodents (Steinberger et al. 1964a,b, Steinberger \& Steinberger 1967). However, they were unable to progress spermatogenesis beyond the pachytene stage, where a critical checkpoint eliminates meiotic cells with aberrant alignment of homologous chromosomes or/and DNA strand break (DSB) (Hunt \& Hassold 2002). Based on the results from mice lacking meiotic components, the pachytene checkpoint is more rigorous in spermatogenesis than oogenesis. This difference might have caused a disruption of spermatogenesis in the organ culture. Recently, the comprehensive evaluation of culture conditions using meiosis- and haploid-specific reporter mice has made it possible to overcome this barrier. A novel culture method using agarose gel and Knockout Serum Replacement instead of fetal calf serum (FCS) produced functional spermatozoa harboring the haploid genome (Sato et al. 2011a). Moreover, eggs fertilized with the spermatozoa gave rise to healthy offspring, confirming that the culture system was successful at reconstituting spermatogenesis in the testis. The culture system is robust, as it succeeded in producing functional 


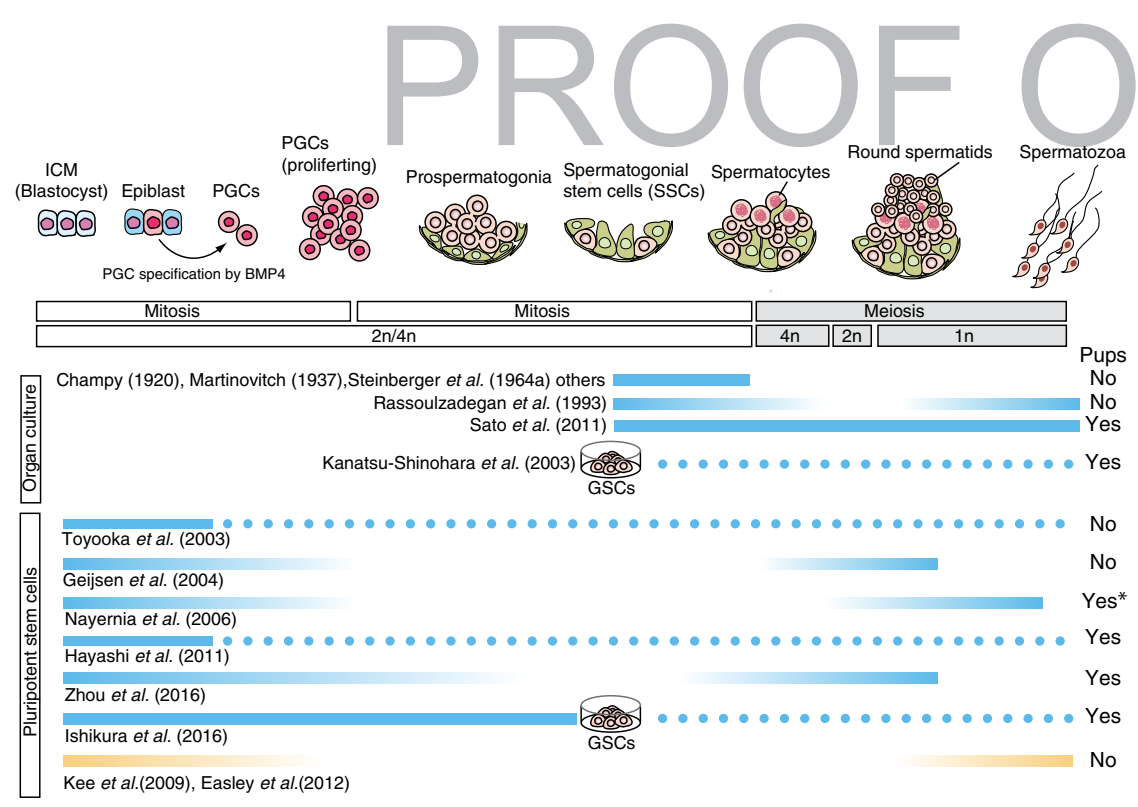

Figure 3 Summary of representative studies on in vitro spermatogenesis. Spermatogenesis is also reconstituted by either organ culture or using pluripotent stem cells. Representative studies in each method are shown. The spermatogenic process reconstituted by each study is shown in blue (mice) or orange (humans) lines. Dashed lines indicate that the processes were bypassed by transplantation. A line fading away indicates that the processes are not fully determined. Establishment of GSCs is a remarkable achievement for reconstitution of in vitro spermatogenesis, as the number of cells can be propagated in culture. Through GSCs, it may be possible to complete in vitro spermatogenesis from pluripotent stem cells. ${ }^{*}$ The offspring were either smaller or larger than wild-type mice and died prematurely from 5 days to 5 months after birth. sperm from the adult testis (Sato et al. 2015) as well as from frozen-thawed testicular tissues (Yokonishi et al. 2014). These studies suggest the possibility of applying the organ culture for the preservation of fertility.

\section{Reconstitution of the male germ line: establishment of germline stem cells}

Among the germ cell lineage, only SSCs meet the definition of stem cells, i.e., cells that can self-renew and differentiate simultaneously. For many years, the propagation of functional SSCs in culture has long been sought but remains elusive, even by enforced expression of T antigen or telomerase (Feng et al. 2002, van Pelt et al. 2002). A key finding in this regard was provided by the genetic analysis of glial cell-derived neurotrophic factor (GDNF), a critical factor for the self-renewal of SSCs. Transgenic mice overexpressing GDNF showed accumulation of undifferentiated spermatogonia in the testes (Meng et al. 2000). On the other hand, gene disruption of a Gdnf allele caused gradual decline of spermatogenesis and resulted in male infertility (Meng et al. 2000). Based on genetic studies and the careful evaluation of culture conditions, it was clearly demonstrated that functional SSCs could be propagated under a culture condition with GDNF as well as FGF2, EGF, LIF and a minimal volume (1\%) of FCS (KanatsuShinohara et al. 2003). The clusters of spermatogonia indefinitely maintained under these conditions were named germline stem cells (GSCs), and these cells can also differentiate into functional spermatozoa upon transplantation into seminiferous tubules of the recipients (Fig. 3). The proliferation of these cells was GDNF dependent, reinforcing the notion that GSCs are a useful material to understand the mechanisms underlying self-renewal of SSCs. Indeed, genetic and biochemical analyses using GS cells suggested that transcription factors, such as Etv5, Bcl6, Oct4, Oct6,
Taf4b and Foxo1 and signaling molecules, such as AKT, MEK and H-Ras, are crucial factors for self-renewal of SSCs (Kanatsu-Shinohara \& Shinohara 2013). GSCs are also useful to provide genetic manipulation in the germ line. Transgenic and gene-disrupted mice were generated through GS cells (Nagano et al. 2001, KanatsuShinohara et al. 2006). So far, the robust production of GSCs was successful in limited species of mice, rats and hamsters (Hamra et al. 2005, Ryu et al. 2005, KanatsuShinohara et al. 2008). Identification of another factor(s) may be required for the development of a culture system that allows GSCs of other species to proliferate.

Combined with the organ culture system, the entire process of spermatogenesis can be reconstituted. GSCs transplanted into the seminiferous tubules of testes on the organ culture system gave rise to functional spermatozoa (Fig. 3) (Sato et al. 2011b). This demonstrates that self-renewing GSCs can differentiate into functional spermatozoa in culture. This technology may be useful for real-time observation of how GSCs settle in the niche and differentiate into spermatozoa. Since the differentiation of GSCs in culture is limited, the combined organ culture system is currently the only path through which GSCs complete meiosis and spermiogenesis (Fig. 3).

\section{Reconstitution of the male germ line: derivation of GSCs from mouse ESCs/iPSCs}

Given that GSCs are derived from ESCs/iPSCs, mature sperm could be derived from pluripotent stem cells in combination with the organ culture system. Recently, Ishikura and coworkers reported the successful derivation of GSCs from mouse ESCs (Fig. 3) (Ishikura et al. 2016). In their study, PGCLCs derived from male ESCs were aggregated with somatic cells dissociated from male E12.5 gonads, which eventually reformed seminiferous tubular structures incorporated with 
PGCLCs. In the reconstituted tubules, PGCLCs differentiated into spermatogonia expressing PLZF. PGCLC-derived spermatogonia were then cultured under a condition for GSCs, which resulted in the successful derivations of several lines of GSC-like cells (GSCLCs) with the capability for infinite proliferation. The GSCLCs expressed representative marker genes, such as Plzf, Id4 and Gfra1, at levels comparable to those in bona fide GSCs. These GSCLCs were apparently functional, as they differentiated into mature sperm in the transplanted testes, and the resultant sperm were capable of fertilization and full-term development. However, it was also found that the efficiency of spermatogenesis completion varied among the GSCLC lines: in some lines spermatogenesis was frequently compromised in the transplanted testes. In these cases, the defective spermatogenesis might have been due to aberrant $\mathrm{CpG}$ methylation at the regulatory elements important for spermatogenesis (Ishikura et al. 2016). This is consistent with a report in which embryonic GSCs derived from fetal prospermatogonia exhibited aberrant CpG methylation that was inheritable by the subsequent generations (Lee et al. 2009). Since dynamic epigenetic alteration is accomplished at the fetal stage, prospermatogonia may be sensitive to manipulation in culture.

\section{Reconstitution of the male germ line: direct derivation of haploid cells from male ESCs/iPSCs}

Several reports have shown that haploid cells can be derived directly from mouse ESCs/iPSCs in culture (Fig. 3). Most of the culture strategy relies on spontaneous differentiation with some factors such as retinoic acid (RA). Geijsen and coworkers reported a culture system that produced haploid cells from ESCs through embryoid bodies (Geijsen et al. 2004). The haploid cells could be incorporated into eggs by intracytoplasmic injection, but the functionality of the zygotes has not been tested. Nayernia and coworkers further developed a culture system that produced haploid cells from ESCs that seemingly had the potential to give rise to offspring (Nayernia et al. 2006). However, the resultant offspring were apparently not healthy, as they were either smaller or larger than controls and showed premature death between 5 days and 5 months after birth. Recently, Zhou and coworkers reported a more robust system, in which haploid round spermatid could be derived from mouse ESCs (Zhou et al. 2016). In this culture system, which was based on those in the previous reports (Hayashi et al. 2011, 2012), PGCLCs were derived from ESCs and then cultured with $W / W v$ germ cell-deficient testicular cells. In a culture with combined media (with RA, BMP2/4/7 and activin A from 0 to 6 days of culture and with testosterone, $\mathrm{FSH}$ and bovine pituitary extract from 7 to 14 days of culture), round spermatids emerged within 2 weeks. The round spermatids possessed similar patterns of gene expression and of epigenetic states in the imprinting loci to spermatids in vivo. The resultant spermatids were injected into wild-type eggs, and the zygotes gave rise to offspring.

The sequence of technological developments leads us to believe that the production of male gametes, or at least haploid cells, from mouse ESCs in culture may be feasible. However, it is premature to reach a conclusion in this regard, since both the experimental and biological reproducibility remain to be evaluated. Since some culture technologies include complicated processes that sometimes yield different results, it is of particular importance to reproduce the experimental procedure with detailed protocols provided by the authors. It is also a concern that the differentiation process is accelerated in all the culture systems. It usually takes about 6 weeks to differentiate mature sperm from PGCs via prospermatogonia in vivo, whereas it requires only 2-3 weeks to progress from PGCLCs to haploid spermatid in culture (Zhou et al. 2016), and thus, the latter process is unlikely to recapitulate faithfully gametogenesis in vivo. Similarity between in vivo and in vitro gametogenesis or so-called 'biological reproducibility', seems particularly important, as evidence shows that prospermatogonia undergo dynamic epigenetic rearrangement (Davis et al. 2000, Ueda et al. 2000, Ly et al. 2015) and are likely sensitive to manipulation in culture (Lee et al. 2009, Ishikura et al. 2016). Moreover, biological reproducibility is also an important criterion when evaluating whether a culture system can be used as a model that can replace experimental animals.

Similar to the results in the mouse model, several reports have demonstrated the production of haploid cells directly from human ESCs/iPSCs (Fig. 3). Although these culture systems successfully halved the genome in the cells, it is difficult to provide a definition for ensuring that the haploid cells are male gametes. Functionality and/or morphology would be criteria for the definition, but the functionality would have never been evaluated, unless fertility and developmental potential are tested, which is not feasible in humans. Also, no report has confirmed that these systems yield mature sperm with their characteristic morphology. As shown in the mouse model, the differentiation process in vitro was much faster than that in vivo: it took only 10-14 days in vitro, whereas it usually takes at least months in the embryo for PGCs to progress to (pro)spermatogonia and approximate 60 days in the testis for spermatogonia to become mature sperm in humans. This leads to a similar concern of epigenetic aberrance in the haploid cells. Whether the culture system produces functional haploid cells through a canonical differentiation process must be tested using, for example, non-human primates. Recent reports have shown that the manner of PGC specification is largely conserved between humans, monkeys and even pigs (Kobayashi et al. 2017), making these reasonable animals to consider when modeling the production of functional haploid cells in humans. 


\section{Brief summary of male infertility}

Recent reports have estimated that almost $15 \%$ of couples are infertile worldwide (Inhorn \& Patrizio 2015), with more than half of these cases being attributable to factors in the male partner. Male infertility is due to genetic abnormalities in 15-20\% of cases, and most of these resulted in oligospermia or azoospermia. Male infertility has both congenital and acquired causes: the former are triggered by genetic disorders including chromosomal and single gene deficiency, the latter by environmental factors. It can also be categorized into three main groups depending on the causal organ/ tissue: (I) organs/tissues outside of the reproductive organs (e.g., disorders of the hypothalamus and pituitary gland and related endocrine disorders), (II) accessory reproductive organs (e.g., disorders of the prostate gland and seminal vesicle and related ejaculatory disorders) and (III) reproductive organs. Moreover, in the testis, spermatogenesis involves the cooperative actions of multiple cellular types, including germ cells and somatic cells. Therefore, the causes of male infertility can be further divided into either germ cell or somatic cell defects. Due to the focus of this review, we will focus on male infertility caused by germ cell defects. However, other more comprehensive reviews are available to overview the complexity of male infertility (Neto et al. 2016a,b, Craig et al. 2017, Krausz \& Casamonti 2017).

One of the major types of genetic abnormalities that have been well defined as a cause of male sterility are the chromosomal abnormalities, such as XXY Klinefelter syndrome, $Y$ chromosome microdeletions and $X Y, X$ mixed gonadal dysgenesis. $X X Y$ individuals have an additional $X$ chromosome caused by nondisjunction of homologous recombination at meiosis (Hansmann 1979). Although the detailed mechanisms triggering germ cell loss remain elusive, XXY Klinefelter syndrome has been associated with early and progressive loss of germ cells in the testes (Ferguson-Smith 1959, Mroz et al. 1999). In terms of $Y$ chromosome microdeletions, the azoospermia factor (AZF) region was mapped in 1996 (Vogt et al. 1996). The mapping revealed that AZF consists of 3 distinct regions, ' $a$ ', ' $b$ ' and ' $c$ ', which contain 3, 11 and 7 protein-coding genes, respectively (5 genes are overlapped in $\mathrm{b}$ and $\mathrm{c}$ regions). Either of these mutations is found in around $10 \%$ of azoospermic patients and 3\% of infertile patients with severely reduced sperm counts (Reijo et al. 1995, Vogt et al. 1996, Yu et al. 2015). Apart from defects related to the chromosomal disorders, it is proposed that single gene mutations may also cause male infertility: comparative analyses indicate a number of genes shown in Table 1. Although the mutations and variants were observed in the loci, it is impossible to experimentally define the causal relationship to the genes in humans, unless the gene function is rescued in the patient. In vitro gametogenesis may be an option to evaluate the gene function on male gametogenesis (see below).
In recent years, lifestyle factors, and particularly metabolic state, have attracted attention as potential causes of male fertility. Thus, aspects of metabolic syndrome such as obesity and diabetes have been reported to decrease male fertility. However, the mechanisms underlying these associations are not well understood. In the testis, Sertoli cells, which provide nutrition to germ cells, preferentially import glucose and export lactate. Although the biological meaning of this lactate preference is not clear, developing germ cells have been shown to utilize lactate and thereby to induce antiapoptotic effects (Erkkila et al. 2002). Some metabolites are tightly related to epigenetic regulation. For example, alpha-ketoglutaric acid (aKG) has co-enzymatic activity for the Jmjd family of histone demethylases and TETmediated CpG hydroxymethylation (Losman \& Kaelin 2013). S-Adenosyl methionine is a substrate of histone and CpG methylation. There are several types of spermatogenesis-specific epigenetic regulations in the maintenance of SSCs, global transcriptional repression in meiotic sex chromosome inactivation and the histone-to-protamine transition at spermiogenesis. It is also known that metabolic phenotypes are transduced beyond generations through possibly epigenetic modifications. Therefore, understanding the relation between metabolites and epigenetics in spermatogenesis is of particular importance.

Male infertility is induced by gonadotoxic treatments, which are typically chemotherapy and/or radiotherapy for cancer (Meistrich 2013). Since these treatments preferentially affect dividing cells, the spermatogonial pool is damaged in the testes. Indeed, a large proportion of cancer survivors suffer from azoospermia and oligospermia (Howell \& Shalet 2005). In addition, toxicities induce chromosomal abnormalities, which are also a serious concern in spermatogenesis. At the present time, although semen cryopreservation is recommended in such cases, it is only applied for postpubertal patients. Although preservation of testicular tissue and/or SSCs is a kind of solution, it could not exclude the risk for re-introduction of cancer cells. To overcome these problems, GSCs and an organ culture system would be an option (Fig. 4) (see below).

\section{Perspectives on contribution of in vitro gametogenesis to male infertility}

How in vitro gametogenesis could contribute to a cure for male infertility is a complex issue (Fig. 4). Needless to say, it is premature, from both an ethical and a technical point of view, to allow attempts to create individuals from haploid cells derived from human ESCs/iPSCs. What about organ culture? In the case of mice, sperm can be produced in an organ culture system. Given that this system is applicable to humans, it could be useful for sperm production from patients with infertility caused by cancer therapy and/or some genetic disorders. As described 
Table 1 Comparative analysis of genes that may cause infertility in humans and mice,

\begin{tabular}{|c|c|c|c|c|c|}
\hline Gene & Chr. & Feature & Reference & $\begin{array}{l}\text { Mouse KO phenotype } \\
\text { (fertility in male) }\end{array}$ & Reference \\
\hline CATSPR 1 & 11 & Cation channel & Avenarius et al. (2009) & $\begin{array}{l}\text { Defects in sperm motility } \\
\text { and fertilization (infertile) }\end{array}$ & Ren et al. (2001) \\
\hline CATSPR2 & 15 & Cation channel & Avidan et al. (2003) & $\begin{array}{l}\text { Failure to acquire } \\
\text { hyperactivated mortility } \\
\text { (infertile) }\end{array}$ & Quill et al. (2003) \\
\hline CREM & 10 & Transcription factor & Krausz \& Sassone-Corsi (2005) & $\begin{array}{l}\text { Spermatids fail to } \\
\text { differentiate into sperm } \\
\text { (infertile) }\end{array}$ & Blendy et al. (1996) \\
\hline$D A Z L$ & 3 & RNA-binding protein & Tung et al. (2006) & $\begin{array}{l}\text { Almost complete absense of } \\
\text { germ cells byond the } \\
\text { spermatogonia (infertile) }\end{array}$ & Ruggiu et al. (1997) \\
\hline DNMT3L & 21 & $\begin{array}{l}\text { Similarity to DNA } \\
\text { methyltransferases }\end{array}$ & Stouffs et al. (2011) & $\begin{array}{l}\text { Arrested and died around the } \\
\text { early meiotic stage } \\
\text { (infertile) }\end{array}$ & Bourc'his \& Bestor (2004) \\
\hline FKBP6 & 7 & $\begin{array}{l}\text { Cis-trans peptidyl-prolyl } \\
\text { isomerase }\end{array}$ & Zhang et al. (2007) & $\begin{array}{l}\text { Absence of normal pachytene } \\
\text { spermatocyte (infertile) }\end{array}$ & Crackower et al. (2003) \\
\hline KIT & 4 & $\begin{array}{l}\text { Type } 3 \text { transmembrane } \\
\text { receptor }\end{array}$ & Galan et al. (2006) & $\begin{array}{l}\text { Defects in proliferation and } \\
\text { differentiation of } \\
\text { spermatogonia (infertile) }\end{array}$ & Ohta et al. (2003) \\
\hline KITLG & 12 & $\begin{array}{l}\text { Ligand of the tyrosine-kinase } \\
\text { receptor KIT }\end{array}$ & Galan et al. (2006) & $\begin{array}{l}\text { Fails to continue } \\
\text { spermatogonial } \\
\text { differentiation (infertile) }\end{array}$ & Brannan et al. (1992) \\
\hline МСM8 & 20 & $\begin{array}{l}\text { Minichromosome } \\
\text { maintenance proteins }\end{array}$ & Tenenbaum-Rakover et al. (2015) & $\begin{array}{l}\text { Spermatocytes are blocked in } \\
\text { meiotic prophase I } \\
\text { (infertile) }\end{array}$ & Lutzmann et al. (2012) \\
\hline MEI1 & 22 & $\begin{array}{l}\text { Meiotic double-stranded } \\
\text { break formation }\end{array}$ & Sato et al. (2006) & $\begin{array}{l}\text { Meiotic arrest caused by } \\
\text { defects in chromosome } \\
\text { synapsis (infertile) }\end{array}$ & Libby et al. (2003) \\
\hline NANOS1 & 10 & $\begin{array}{l}\text { CCHC-type zinc finger } \\
\text { protein }\end{array}$ & Kusz-Zamelczyk et al. (2013) & $\begin{array}{l}\text { No obvious impairment } \\
\text { (fertile) }\end{array}$ & Haraguchi et al. (2003) \\
\hline NANOS2 & 19 & $\begin{array}{l}\text { CCHC-type zinc finger } \\
\text { protein }\end{array}$ & Kusz et al. (2009b) & $\begin{array}{l}\text { Complete loss of } \\
\text { spermatogonia (infertile) }\end{array}$ & Tsuda et al. (2003) \\
\hline NANOS3 & 19 & $\begin{array}{l}\text { CCHC-type zinc finger } \\
\text { protein }\end{array}$ & Kusz et al. (2009a) & $\begin{array}{l}\text { Complete loss of germ cell } \\
\text { (infertile) }\end{array}$ & Tsuda et al. (2003) \\
\hline NPAS2 & 2 & $\begin{array}{l}\text { bHLH-PAS family of } \\
\text { transcription factors }\end{array}$ & Ramasamy et al. (2015) & $\begin{array}{l}\text { Morphologically } \\
\text { indistinguishable (fertile) }\end{array}$ & Garcia et al. (2000) \\
\hline PICK1 & 22 & Adaptor protein & Liu et al. (2010) & $\begin{array}{l}\text { Disrupting acrosome } \\
\text { formation (infertile) }\end{array}$ & Xiao et al. (2009) \\
\hline PIWI (HIWI) & 12 & Argonaute protein & Gou et al. (2017) & $\begin{array}{l}\text { Arrested at the beginning of } \\
\text { the round spermatid } \\
\text { (infertile) }\end{array}$ & Deng \& Lin (2002) \\
\hline PRDM9 & 5 & $\begin{array}{l}\text { Zinc finger protein with } \\
\text { histone methyltransferase } \\
\text { activity }\end{array}$ & Irie et al. (2009) & $\begin{array}{l}\text { Severe impairment of the } \\
\text { double-strand break repair } \\
\text { pathway (infertile) }\end{array}$ & Hayashi et al. (2005) \\
\hline SOHLH1 & 9 & Transcription factor & Choi et al. (2010) & $\begin{array}{l}\text { Spermatogonia does not } \\
\text { differentiate properly } \\
\text { (infertile) }\end{array}$ & Suzuki et al. (2012) \\
\hline SYCE 1 & 10 & Synaptonemal complex & Maor-Sagie et al. (2015) & $\begin{array}{c}\text { Synaptonemal complex do } \\
\text { not assembled (infertile) }\end{array}$ & Bolcun-Filas et al. (2009) \\
\hline SYCP3 & 12 & Synaptonemal complex & Miyamoto et al. (2003) & $\begin{array}{l}\text { Massive apoptotic cell death } \\
\text { during meiotic prophase } \\
\text { (infertile) }\end{array}$ & Yuan et al. (2000) \\
\hline TAF4B & 18 & $\begin{array}{l}\text { TATA-box-binding protein } \\
\text { associated factor }\end{array}$ & Ayhan et al. (2014) & $\begin{array}{l}\text { Gonocyte proliferation is } \\
\text { impaired (gradually } \\
\text { infertile) }\end{array}$ & Falender et al. (2005) \\
\hline TEX11 & $X$ & $\begin{array}{l}\text { Containes TRP protein- } \\
\text { protein interaction } \\
\text { domain }\end{array}$ & Yatsenko et al. (2015) & $\begin{array}{l}\text { Spermatocytes apoptosis at } \\
\text { pachytene (infertile) }\end{array}$ & Yang et al. (2008b) \\
\hline TEX15 & 8 & $\begin{array}{l}\text { Serine-rich protein with no } \\
\text { known function motifs }\end{array}$ & Okutman et al. (2015) & $\begin{array}{l}\text { Spermatocytes exhibit a } \\
\text { failure in chromosomal } \\
\text { synapsis (infertile) }\end{array}$ & Yang et al. (2008a) \\
\hline ZMYND15 & 17 & $\begin{array}{l}\text { MYND-containing } \\
\text { zinc-binding protein }\end{array}$ & Ayhan et al. (2014) & $\begin{array}{l}\text { Depletion of late spermatids } \\
\text { (infertile) }\end{array}$ & Yan et al. (2010) \\
\hline ZNF230 & 19 & Zinc finger protein & Dong et al. (2005) & $\begin{array}{l}\text { No obvious impairment } \\
\quad \text { (fertile) }\end{array}$ & Liu et al. (2014) \\
\hline
\end{tabular}




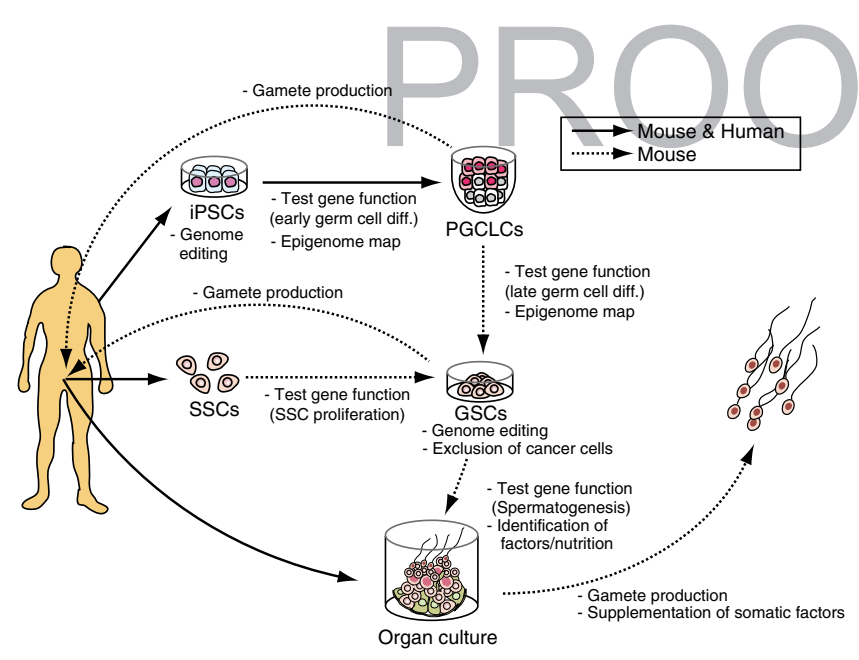

Figure 4 Possible contributions of in vitro spermatogenesis to male infertility. There are several pathways to reconstitute spermatogenesis in vitro, most of which are demonstrated only in mice (dashed arrows). Gamete productions can be done through PGCLCs or GSCs followed by transplantation. Organ culture system is currently the only path to complete spermatogenesis. In vitro reconstitution of spermatogenesis will contribute to a better understanding of gene function, epigenome and factors/nutrition essential for the process. Although these options in humans are limited (solid arrows), in vitro spermatogenesis would be utilized for a variety of purposes. Since human materials in vivo are limited, the reconstitution would be a valuable option to investigate biological processes.

earlier, the autotransplantation of testicular tissue and/or SSCs into the testes after cancer treatment is an option to preserve the fertility of cancer patients. This process may be disturbed by inefficient transplantation resulting in few cells with reconstitution of spermatogenesis—and/or by contamination of cancer cells causing recurrence of the disease. Organ culture of the testicular tissue would be an option to obviate these risks (Fig. 4). This possibility seems promising, since in mice, it is known that functional sperm can be obtained from frozen-thawed testicular tissues by an organ culture system (Yokonishi et al. 2014).

In the case of genetic disorders, one possible treatment strategy has been proposed based on experimental evidence. Namely, Sato and coworkers succeeded in restoring spermatogenesis in $S / / S I^{d}$ mutant testes bearing mutations in genes encoding SCF by culturing with recombinant SCF (Sato et al. 2012). This strategy would be particularly effective in cases in which the mutation is in a gene encoding a somatic factor and/or soluble factor, because such defects can be compensated by simply adding the recombinant protein to the medium (Fig. 4). The strategy may also be useful for male infertility with acquired causes-e.g., environmental factors, such as nutrition and metabolites, that cause infertility can be controlled in culture, which may overcome the defect in spermatogenesis. Since immunorejection may be ignored in an organ culture system, it is feasible to insert spermatogonia into allogeneic seminiferous tubules. This would be effective for infertility caused by defects in somatic cells and/or environmental factors.

From a purely technological point of view, gene editing may be an option to cure infertility caused by single gene mutations (Fig. 4). Genome editing systems, such as zinc finger nucleases, TALENs and CRISPR-Cas9, have been rapidly developed over the last decade, making it feasible to edit the genome efficiently. By using GSCs, and correcting the gene mutation, followed by selection of a GSC clone with the correction (Chapman et al. 2015, Wu et al. 2015), it would theoretically be possible to get rid of any kind of gene mutation(s). Naturally, application of these genome editing techniques to the human germ line will necessitate a social debate on technological safety and bioethics. A part of the concern is that the genome editing systems sometimes have off-target effects that could cause an alternative gene mutation. This possibility could be excluded by using GSCs, since the entire genomic sequence can be checked in order to choose the desired GSC clones for propagation and use. Genetic and epigenetic stability would also become critical factors, once GSCs were established in humans. It has been reported that the genetic and epigenetic states in GSCs in mice are relatively stable (Kanatsu-Shinohara et al. 2005), reinforcing the notion that GSCs might one day be a strategy for male infertility. In addition to the genome editing, it may be feasible to eliminate excess chromosomes, such as one of the $X$ chromosomes in XXY, from the GSCs spontaneously (Hirota et al. 2017) or by using a Cre-mediated recombination system (Matsumura et al. 2007).

At the present time, it seems more promising to use in vitro gametogenesis as a model system rather than an alternative source of gametes. First, an organ culture system would provide a platform that allows continuous observation of spermatogenesis. Since spermatogenesis includes various complicated processes, including meiosis and spermiogenesis, this platform would provide a better understanding of spermatogenesis. A culture device suitable for long-term culture with a liveimaging system has recently been under development (Komeya et al. 2016). A robust organ culture system would have a range of important applications for male infertility, such as the identification of key nutrients and their metabolic pathways, the screening of drugs that could cure male infertility or the testing of possible irritants that could disturb spermatogenesis. Because the genomes of GSCs can be manipulated, a functional assay for genes of interest by forced expression and/or knockout would be a powerful tool to identify genes critical for spermatogenesis (Fig. 4). Such an assay would be even more powerful if patient-specific GSCs could be routinely established. Then, causal relationships between gene mutations and symptoms would be easier to establish at the experimental level. Because the transplantation of GSCs also makes it possible to distinguish germ cell-intrinsic effects from somatic environmental effects, experiments combining both techniques-i.e., gene editing in GSCs followed 
by transplantation into testes in culture-would be an efficient approach for elucidating the detailed functions of genes. Taking these facts together, it is expected that in vitro methods will accelerate our understanding of spermatogenesis and male fertility.

\section{Concluding remarks}

In vitro gametogenesis using an organ culture system, ESCs, iPSCs or GSCs, can provide functional gametes in mice. These technologies can be beneficial in two different ways, either as an alternative source of gametes or as a model system that recapitulate gametogenesis in vivo. The quality of the gametes produced in vitro is the critical outcome. Recent experiments in mice have clearly shown that the quality of the gametes in vitro is inferior to that of the gametes in vivo, due, at least in part, to aberrant differentiation processes under suboptimal culture conditions. Further refinement of the culture conditions can thus be expected to increase the utility of in vitro gametogenesis. Reproductive biology and in vitro gametogenesis are most advanced in mice, and it will not be easy to generalize the murine gametogenesis method to humans and other animals. In particular, germ cell development requires the shortest length of time in mice. Because of this problem, together with the above-mentioned issues with quality, the study of in vitro gametogenesis has only just begun and constant efforts will be required for development of the technology.

\section{Declaration of interests}

The authors declare that there is no conflict of interest that could be perceived as prejudicing the impartiality of this review.

\section{Funding}

This study was supported in part by a Grant-in-Aid from the Ministry of Education, Culture, Sports, Science, and Technology of Japan (KAKENHI \#25114006) by the Uehara Memorial Foundation and by the Takeda Science Foundation.

\section{Acknowledgement}

The authors thank $M$ Shono for reading of the manuscript and members for helpful comments. The authors apologize to colleagues whose work could not be cited owing to length limitations.

\section{References}

Adams IR \& McLaren A 2002 Sexually dimorphic development of mouse primordial germ cells: switching from oogenesis to spermatogenesis. Development 129 1155-1164.

Avenarius MR, Hildebrand MS, Zhang Y, Meyer NC, Smith LL, Kahrizi K, Najmabadi H \& Smith RJ 2009 Human male infertility caused by mutations in the CATSPER1 channel protein. American Journal of Human Genetics 84 505-510. (https://doi.org/10.1016/j.ajhg.2009.03.004)
Avidan N, Tamary H, Dgany O, Cattan D, Pariente A, Thulliez M, Borot N, Moati L, Barthelme A, Shalmon L et al. 2003 CATSPER2, a human autosomal nonsyndromic male infertility gene. European Journal of Human Genetics 11 497-502. (https://doi.org/10.1038/sj.ejhg.5200991)

Ayhan O, Balkan M, Guven A, Hazan R, Atar M, Tok A \& Tolun A 2014 Truncating mutations in TAF4B and ZMYND15 causing recessive azoospermia. Journal of Medical Genetics 51 239-244. (https://doi. org/10.1136/jmedgenet-2013-102102)

Blendy JA, Kaestner KH, Weinbauer GF, Nieschlag E \& Schutz G 1996 Severe impairment of spermatogenesis in mice lacking the CREM gene. Nature 380 162-165. (https://doi.org/10.1038/380162a0)

Bolcun-Filas E, Hall E, Speed R, Taggart M, Grey C, de Massy B, Benavente R \& Cooke HJ 2009 Mutation of the mouse Syce1 gene disrupts synapsis and suggests a link between synaptonemal complex structural components and DNA repair. PLoS Genetics 5 27. (https://doi. org/10.1371/annotation/50260271-aed9-4316-b09a-304591b0cba5)

Bourc'his D \& Bestor TH 2004 Meiotic catastrophe and retrotransposon reactivation in male germ cells lacking Dnmt3L. Nature 431 96-99.

Brannan CI, Bedell MA, Resnick JL, Eppig JJ, Handel MA, Williams DE, Lyman SD, Donovan PJ, Jenkins NA \& Copeland NG 1992 Developmental abnormalities in Steel17H mice result from a splicing defect in the steel factor cytoplasmic tail. Genes and Development 6 1832-1842. (https://doi.org/10.1101/gad.6.10.1832)

Champy C 1920 Quelques résultats de la méthode de culture des tissues. Archives de Zoologie Expérimentale et Générale 60 461-500.

Chapman KM, Medrano GA, Jaichander P, Chaudhary J, Waits AE, Nobrega MA, Hotaling JM, Ober C \& Hamra FK 2015 Targeted germline modifications in rats using CRISPR/Cas 9 and spermatogonial stem cells. Cell Reports 10 1828-1835. (https://doi.org/10.1016/j.celrep.2015.02.040)

Choi Y, Jeon S, Choi M, Lee MH, Park M, Lee DR, Jun KY, Kwon Y, Lee $\mathbf{O H}$, Song SH et al. 2010 Mutations in SOHLH1 gene associate with nonobstructive azoospermia. Human Mutation 31 788-793. (https://doi. org/10.1002/humu.21264)

Crackower MA, Kolas NK, Noguchi J, Sarao R, Kikuchi K, Kaneko H, Kobayashi E, Kawai Y, Kozieradzki I, Landers R et al. 2003 Essential role of Fkbp6 in male fertility and homologous chromosome pairing in meiosis. Science 300 1291-1295. (https://doi.org/10.1126/science.1083022)

Craig JR, Jenkins TG, Carrell DT \& Hotaling JM 2017 Obesity, male infertility, and the sperm epigenome. Fertility and Sterility 107 848-859. (https://doi.org/10.1016/j.fertnstert.2017.02.115)

Davis TL, Yang GJ, McCarrey JR \& Bartolomei MS 2000 The H19 methylation imprint is erased and re-established differentially on the parental alleles during male germ cell development. Human Molecular Genetics 9 2885-2894. (https://doi.org/10.1093/hmg/9.19.2885)

Deng W \& Lin H 2002 miwi, a murine homolog of piwi, encodes a cytoplasmic protein essential for spermatogenesis. Developmental Cell 2 819-830. (https://doi.org/10.1016/S1534-5807(02)00165-X)

Dong JT, Zhang SZ, Ma YX, Yang KX, Huang MK, Sun Y, He GP, Li Y, Zhang W \& Peng Y 2005 Screening for ZNF230 gene mutation and analysis of its correlation with azoospermia. Zhonghua Yi Xue Yi Chuan Xue Za Zhi 22 258-260.

Dutta S, MarkKappeler CJ, Hoyer PB \& Pepling ME 2014 The steroid hormone environment during primordial follicle formation in perinatal mouse ovaries. Biology of Reproduction 9168.

Eppig JJ \& O'Brien MJ 1996 Development in vitro of mouse oocytes from primordial follicles. Biology of Reproduction 54 197-207. (https://doi. org/10.1095/biolreprod54.1.197)

Erkkila K, Aito H, Aalto K, Pentikainen V \& Dunkel L 2002 Lactate inhibits germ cell apoptosis in the human testis. Molecular Human Reproduction 8 109-117. (https://doi.org/10.1093/molehr/8.2.109)

Falender AE, Freiman RN, Geles KG, Lo KC, Hwang K, Lamb DJ, Morris PL, Tjian R \& Richards JS 2005 Maintenance of spermatogenesis requires TAF4b, a gonad-specific subunit of TFIID. Genes and Development 19 794-803. (https://doi.org/10.1101/gad.1290105)

Feng LX, Chen Y, Dettin L, Pera RA, Herr JC, Goldberg E \& Dym M 2002 Generation and in vitro differentiation of a spermatogonial cell line. Science 297 392-395. (https://doi.org/10.1126/science.1073162)

Ferguson-Smith MA 1959 The prepubertal testicular lesion in chromatinpositive Klinefelter's syndrome (primary micro-orchidism) as seen in mentally handicapped children. Lancet 1 219-222. (https://doi. org/10.1016/S0140-6736(59)90049-2)

Gafni O, Weinberger L, Mansour AA, Manor YS, Chomsky E, Ben-Yosef D, Kalma Y, Viukov S, Maza I, Zviran A et al. 2013 Derivation of novel 
human ground state naive pluripotent stem cells. Nature 282-286. (https;//doi.org/10.1038/nture12745).

Galan JJ, De Felici M, Buch B, Rivero MC, Segura A, Royo JL, Cruz N, Real LM \& Ruiz A 2006 Association of genetic markers within the KIT and KITLG genes with human male infertility. Human Reproduction $\mathbf{2 1}$ 3185-3192. (https://doi.org/10.1093/humrep/del313)

Garcia JA, Zhang D, Estill SJ, Michnoff C, Rutter J, Reick M, Scott K, Diaz-Arrastia R \& McKnight SL 2000 Impaired cued and contextual memory in NPAS2-deficient mice. Science 288 2226-2230. (https://doi. org/10.1126/science.288.5474.2226)

Geijsen N, Horoschak M, Kim K, Gribnau J, Eggan K \& Daley GQ 2004 Derivation of embryonic germ cells and male gametes from embryonic stem cells. Nature 427 148-154. (https://doi.org/10.1038/nature02247)

Gou LT, Kang JY, Dai P, Wang X, Li F, Zhao S, Zhang M, Hua MM, Lu Y, Zhu Y et al. 2017 Ubiquitination-deficient mutations in human Piwi cause male infertility by impairing histone-to-protamine exchange during spermiogenesis. Cell 169 1090-1104. (https://doi.org/10.1016/j. cell.2017.04.034)

Hamra FK, Chapman KM, Nguyen DM, Williams-Stephens AA, Hammer RE \& Garbers DL 2005 Self renewal, expansion, and transfection of rat spermatogonial stem cells in culture. PNAS 102 17430-17435. (https://doi.org/10.1073/pnas.0508780102)

Hansmann I 1979 Clustering of chromosomal aneuploidy and tracing of nondisjunction in man. Environmental Health Perspectives 31 23-25. (https://doi.org/10.1289/ehp.793123)

Haraguchi S, Tsuda M, Kitajima S, Sasaoka Y, Nomura-Kitabayashid A, Kurokawa K \& Saga Y 2003 nanos1: a mouse nanos gene expressed in the central nervous system is dispensable for normal development Mechanisms of Development 120 721-731. (https://doi.org/10.1016/ S0925-4773(03)00043-1)

Hayashi K \& Surani MA 2009 Self-renewing epiblast stem cells exhibit continual delineation of germ cells with epigenetic reprogramming in vitro. Development 136 3549-3556. (https://doi.org/10.1242/dev.037747)

Hayashi K, Yoshida K \& Matsui Y 2005 A histone H3 methyltransferase controls epigenetic events required for meiotic prophase. Nature 438 374-378. (https://doi.org/10.1038/nature04112)

Hayashi K, Ohta H, Kurimoto K, Aramaki S \& Saitou M 2011 Reconstitution of the mouse germ cell specification pathway in culture by pluripotent stem cells. Cell 146 519-532. (https://doi.org/10.1016/j. cell.2011.06.052)

Hayashi K, Ogushi S, Kurimoto K, Shimamoto S, Ohta H \& Saitou M 2012 Offspring from oocytes derived from in vitro primordial germ cell-like cells in mice. Science 338 971-975. (https://doi.org/10.1126/science.1226889)

Hikabe O, Hamazaki N, Nagamatsu G, Obata Y, Hirao Y, Hamada N, Shimamoto S, Imamura T, Nakashima K, Saitou M et al. 2016 Reconstitution in vitro of the entire cycle of the mouse female germ line. Nature 539 299-303. (https://doi.org/10.1038/nature20104)

Hirao Y, Itoh T, Shimizu M, Iga K, Aoyagi K, Kobayashi M, Kacchi M, Hoshi H \& Takenouchi N 2004 In vitro growth and development of bovine oocyte-granulosa cell complexes on the flat substratum: effects of high polyvinylpyrrolidone concentration in culture medium. Biology of Reproduction 70 83-91. (https://doi.org/10.1095/biolreprod.103.021238)

Hirota T \& Ohta H PowellBE MahadevaiahSK OjarikreOA SaitouM TurnerJMA 2017 Fertile offspring from sterile sex chromosome trisomic mice. Science 357 932-935. (https://doi.org/10.1126/science.aam9046)

Howell S] \& Shalet SM 2005 Spermatogenesis after cancer treatment: damage and recovery. Journal of the National Cancer Institute Monographs 2005 34 12-17. (https://doi.org/10.1093/jncimonographs/lgi003)

Hunt PA \& Hassold TJ 2002 Sex matters in meiosis. Science 296 2181-2183. (https://doi.org/10.1126/science.1071907)

Iguchi T, Fukazawa Y, Uesugi Y \& Takasugi N 1990 Polyovular follicles in mouse ovaries exposed neonatally to diethylstilbestrol in vivo and in vitro. Biology of Reproduction 43 478-484. (https://doi.org/10.1095/ biolreprod43.3.478)

Inhorn MC \& Patrizio P 2015 Infertility around the globe: new thinking on gender, reproductive technologies and global movements in the 21st century. Human Reproduction Update 21 411-426. (https://doi. org/10.1093/humupd/dmv016)

Irie S, Tsujimura A, Miyagawa $\mathrm{Y}$, Ueda T, Matsuoka $\mathrm{Y}$, Matsui $\mathrm{Y}$, Okuyama A, Nishimune Y \& Tanaka H 2009 Single-nucleotide polymorphisms of the PRDM9 (MEISETZ) gene in patients with nonobstructive azoospermia. Journal of Andrology 30 426-431. (https://doi.org/10.2164/jandrol.108.006262)
Irie N, Weinberger L, Tang WW, Kobayashi T, Viukov S, Manor YS, Dietmann S, Hanna JH \& Surani MA 2015 SOX17 is a critical specifier of human primordial germ cell fate. Cell 160 253-268. (https://doi. org/10.1016/j.cell.2014.12.013)

Ishikura Y, Yabuta Y, Ohta H, Hayashi K, Nakamura T, Okamoto I, Yamamoto T, Kurimoto K, Shirane K, Sasaki H et al. 2016 In vitro derivation and propagation of spermatogonial stem cell activity from mouse pluripotent stem cells. Cell Reports 17 2789-2804. (https://doi. org/10.1016/j.celrep.2016.11.026)

Jameson SA, Natarajan A, Cool J, DeFalco T, Maatouk DM, Mork L, Munger SC \& Capel B 2012 Temporal transcriptional profiling of somatic and germ cells reveals biased lineage priming of sexual fate in the fetal mouse gonad. PLOS Genetics 8 e1002575. (https://doi.org/10.1371/ journal.pgen.1002575)

Kanatsu-Shinohara M \& Shinohara T 2013 Spermatogonial stem cell self-renewal and development. Annual Review of Cell and Developmental Biology 29 163-187. (https://doi.org/10.1146/annurevcellbio-101512-122353)

Kanatsu-Shinohara M, Ogonuki N, Inoue K, Miki H, Ogura A, Toyokuni S \& Shinohara T 2003 Long-term proliferation in culture and germline transmission of mouse male germline stem cells. Biology of Reproduction 69 612-616. (https://doi.org/10.1095/biolreprod.103.017012)

Kanatsu-Shinohara M, Ogonuki N, Iwano T, Lee J, Kazuki Y, Inoue K, Miki H, Takehashi M, Toyokuni S, Shinkai Y et al. 2005 Genetic and epigenetic properties of mouse male germline stem cells during longterm culture. Development 132 4155-4163. (https://doi.org/10.1242/ dev.02004)

Kanatsu-Shinohara M, Ikawa M, Takehashi M, Ogonuki N, Miki H, Inoue K, Kazuki Y, Lee J, Toyokuni S, Oshimura M et al. 2006 Production of knockout mice by random or targeted mutagenesis in spermatogonial stem cells. PNAS 103 8018-8023. (https://doi.org/10.1073/ pnas.0601139103)

Kanatsu-Shinohara M, Muneto T, Lee J, Takenaka M, Chuma S, Nakatsuji N, Horiuchi T \& Shinohara T 2008 Long-term culture of male germline stem cells from hamster testes. Biology of Reproduction 78 611-617. (https://doi.org/10.1095/biolreprod.107.065615)

Kezele P \& Skinner MK 2003 Regulation of ovarian primordial follicle assembly and development by estrogen and progesterone: endocrine model of follicle assembly. Endocrinology 144 3329-3337. (https://doi. org/10.1210/en.2002-0131)

Kobayashi T, Zhang H, Tang WWC, Irie N, Withey S, Klisch D, Sybirna A, Dietmann S, Contreras DA, Webb R et al. 2017 Principles of early human development and germ cell program from conserved model systems. Nature 546 416-420. (https://doi.org/10.1038/nature22812)

Komeya M, Kimura H, Nakamura H, Yokonishi T, Sato T, Kojima K, Hayashi K, Katagiri K, Yamanaka H, Sanjo H et al. 2016 Long-term ex vivo maintenance of testis tissues producing fertile sperm in a microfluidic device. Scientific Reports 6 21472. (https://doi.org/10.1038/ srep21472)

Krausz C \& Casamonti E 2017 Spermatogenic failure and the Y chromosome. Human Genetics 136 637-655. (https://doi.org/10.1007/ s00439-017-1793-8)

Krausz C \& Sassone-Corsi P 2005 Genetic control of spermiogenesis: insights from the CREM gene and implications for human infertility. Reproductive BioMedicine Online 10 64-71. (https://doi.org/10.1016/ S1472-6483(10)60805-X)

Kurimoto K, Yabuta Y, Hayashi K, Ohta H, Kiyonari H, Mitani T, Moritoki Y, Kohri K, Kimura H, Yamamoto T et al. 2015 Quantitative dynamics of chromatin remodeling during germ cell specification from Mouse embryonic stem cells. Cell Stem Cell 16 517-532. (https://doi. org/10.1016/j.stem.2015.03.002)

Kusz K, Tomczyk L, Spik A, Latos-Bielenska A, Jedrzejczak P, Pawelczyk L \& Jaruzelska J 2009a NANOS3 gene mutations in men with isolated sterility phenotype. Molecular Reproduction and Development 76804. https://doi.org/10.1002/mrd.21070.

Kusz KM, Tomczyk L, Sajek M, Spik A, Latos-Bielenska A, Jedrzejczak P, Pawelczyk L \& Jaruzelska J 2009b The highly conserved NANOS2 protein: testis-specific expression and significance for the human male reproduction. Molecular Human Reproduction 15 165-171. (https://doi. org/10.1093/molehr/gap003)

Kusz-Zamelczyk K, Sajek M, Spik A, Glazar R, Jedrzejczak P, LatosBielenska A, Kotecki M, Pawelczyk L \& Jaruzelska J 2013 Mutations of NANOS1, a human homologue of the Drosophila morphogen, are 
associated with a lack of germ cells in testes or severe oligo-asthenoteratozoospermia. Journal of Medical Genetics 50 187-193. (https://doi. org/10.1136/jmedgenet-2012-101230)

Lawson KA \& Hage WJ 1994 Clonal analysis of the origin of primordial germ cells in the mouse. Ciba Foundation Symposium 182 68-84.

Lawson KA, Dunn NR, Roelen BA, Zeinstra LM, Davis AM, Wright CV, Korving JP \& Hogan BL 1999 Bmp4 is required for the generation of primordial germ cells in the mouse embryo. Genes and Development 13 424-436. (https://doi.org/10.1101/gad.13.4.424)

Lee J, KanatsuShinohara M, Ogonuki N, Miki H, Inoue K, Morimoto T, Morimoto H, Ogura A \& Shinohara T 2009 Heritable imprinting defect caused by epigenetic abnormalities in mouse spermatogonial stem cells. Biology of Reproduction 80 518-527. (https://doi.org/10.1095/ biolreprod.108.072330)

Lei L, Jin S, Mayo KE \& Woodruff TK 2010 The interactions between the stimulatory effect of follicle-stimulating hormone and the inhibitory effect of estrogen on mouse primordial folliculogenesis. Biology of Reproduction 82 13-22. (https://doi.org/10.1095/biolreprod.109.077404)

Libby BJ, Reinholdt LG \& Schimenti JC 2003 Positional cloning and characterization of Mei1, a vertebrate-specific gene required for normal meiotic chromosome synapsis in mice. PNAS 100 15706-15711. (https://doi.org/10.1073/pnas.2432067100)

Liu G, Shi QW \& Lu GX 2010 A newly discovered mutation in PICK1 in a human with globozoospermia. Asian Journal of Andrology 12 556-560. (https://doi.org/10.1038/aja.2010.47)

Liu Y, Tao D, Lu Y, Yang Y, Ma Y \& Zhang S 2014 Targeted disruption of the mouse testis-enriched gene Znf230 does not affect spermatogenesis or fertility. Genetics and Molecular Biology 37 708-715. (https://doi. org/10.1590/S1415-47572014005000013)

Losman JA \& Kaelin WG Jr 2013 What a difference a hydroxyl makes: mutant IDH, (R)-2-hydroxyglutarate, and cancer. Genes and Development 27 836-852. (https://doi.org/10.1101/gad.217406.113)

Lutzmann M, Grey C, Traver S, Ganier O, Maya-Mendoza A, Ranisavljevic N, Bernex F, Nishiyama A, Montel N, Gavois E et al. 2012 MCM8- and MCM9-deficient mice reveal gametogenesis defects and genome instability due to impaired homologous recombination. Molecular Cell 47 523-534. (https://doi.org/10.1016/j.molcel.2012.05.048)

Ly L, Chan D \& Trasler JM 2015 Developmental windows of susceptibility for epigenetic inheritance through the male germline. Seminars in Cell and Developmental Biology 43 96-105. (https://doi.org/10.1016/j. semcdb.2015.07.006)

Maor-Sagie E, Cinnamon Y, Yaacov B, Shaag A, Goldsmidt H, Zenvirt S, Laufer N, Richler C \& Frumkin A 2015 Deleterious mutation in SYCE1 is associated with non-obstructive azoospermia. Journal of Assisted Reproduction and Genetics 32 887-891. (https://doi.org/10.1007/ s10815-015-0445-y)

Martinovitch P 1937 Development in vitro of the mammalian gonad. Nature 139 413. (https://doi.org/10.1038/139413a0)

Matsumura H, Tada M, Otsuji T, Yasuchika K, Nakatsuji N, Surani A \& Tada T 2007 Targeted chromosome elimination from ES-somatic hybrid cells. Nature Methods 4 23-25. (https://doi.org/10.1038/nmeth973)

McClellan KA, Gosden R \& Taketo T 2003 Continuous loss of oocytes throughout meiotic prophase in the normal mouse ovary. Developmental Biology 258 334-348. (https://doi.org/10.1016/S0012-1606(03)00132-5)

McLaren A \& Lawson KA 2005 How is the mouse germ-cell lineage established? Differentiation 73 435-437. (https://doi.org/10.1111/ j.1432-0436.2005.00049.x)

Meistrich ML 2013 Effects of chemotherapy and radiotherapy on spermatogenesis in humans. Fertility and Sterility 100 1180-1186. (https://doi.org/10.1016/j.fertnstert.2013.08.010)

Meng X, Lindahl M, Hyvonen ME, Parvinen M, de Rooij DG, Hess MW, Raatikainen-Ahokas A, Sainio K, Rauvala H, Lakso M et al. 2000 Regulation of cell fate decision of undifferentiated spermatogonia by GDNF. Science 287 1489-1493. (https://doi.org/10.1126/ science.287.5457.1489)

Miyamoto T, Hasuike S, Yogev L, Maduro MR, Ishikawa M, Westphal H \& Lamb DJ 2003 Azoospermia in patients heterozygous for a mutation in SYCP3. Lancet 362 1714-1719. (https://doi.org/10.1016/S01406736(03)14845-3)

Morohaku K, Tanimoto R, Sasaki K, Kawahara-Miki R, Kono T, Hayashi K, Hirao Y \& Obata Y 2016 Complete in vitro generation of fertile oocytes from mouse primordial germ cells. PNAS 113 9021-9026. (https://doi. org/10.1073/pnas.1603817113)
Mroz K, Carrel L \& Hunt PA 1999 Germ cell development in the XXY mouse: evidence that $X$ chromosome reactivation is independent of sexual differentiation. Developmental Biology 207 229-238. (https://doi. org/10.1006/dbio.1998.9160)

Nagano M, Brinster CJ, Orwig KE, Ryu BY, Avarbock MR \& Brinster RL 2001 Transgenic mice produced by retroviral transduction of male germ-line stem cells. PNAS 98 13090-13095. (https://doi.org/10.1073/ pnas.231473498)

Nakaki F, Hayashi K, Ohta H, Kurimoto K, Yabuta Y \& Saitou M 2013 Induction of mouse germ-cell fate by transcription factors in vitro. Nature.

Nayernia K, Nolte J, Michelmann HW, Lee JH, Rathsack K, Drusenheimer N, Dev A, Wulf G, Ehrmann IE, Elliott DJ et al. 2006 In vitro-differentiated embryonic stem cells give rise to male gametes that can generate offspring mice. Developmental Cell 11 125-132. (https://doi.org/10.1016/j.devcel.2006.05.010)

Neto FT, Bach PV, Najari BB, Li PS \& Goldstein M 2016a Genetics of male infertility. Current Urology Reports 17 70. (https://doi.org/10.1007/ s11934-016-0627-x)

Neto FT, Bach PV, Najari BB, Li PS \& Goldstein M 2016b Spermatogenesis in humans and its affecting factors. Seminars in Cell and Developmental Biology 59 10-26. (https://doi.org/10.1016/j.semcdb.2016.04.009)

Nichols J \& Smith A 2009 Naive and primed pluripotent states. Cell Stem Cell 4 487-492. (https://doi.org/10.1016/j.stem.2009.05.015)

O'Brien MJ, Pendola JK \& Eppig J 2003 A revised protocol for in vitro development of mouse oocytes from primordial follicles dramatically improves their developmental competence. Biology of Reproduction $\mathbf{6 8}$ 1682-1686.

Ohinata Y, Payer B, O'Carroll D, Ancelin K, Ono Y, Sano M, Barton SC, Obukhanych T, Nussenzweig M, Tarakhovsky A et al. 2005 Blimp1 is a critical determinant of the germ cell lineage in mice. Nature $\mathbf{4 3 6}$ 207-213. (https://doi.org/10.1038/nature03813)

Ohinata Y, Ohta H, Shigeta M, Yamanaka K, Wakayama T \& Saitou M 2009 A signaling principle for the specification of the germ cell lineage in mice. Cell 137 571-584. (https://doi.org/10.1016/j.cell.2009.03.014)

Ohta H, Tohda A \& Nishimune Y 2003 Proliferation and differentiation of spermatogonial stem cells in the $\mathrm{w} / \mathrm{wv}$ mutant mouse testis. Biology of Reproduction 69 1815-1821. (https://doi.org/10.1095/ biolreprod.103.019323)

Okutman O, Muller J, Baert Y, Serdarogullari M, Gultomruk M, Piton A, Rombaut C, Benkhalifa M, Teletin M, Skory V et al. 2015 Exome sequencing reveals a nonsense mutation in TEX15 causing spermatogenic failure in a Turkish family. Human Molecular Genetics 24 5581-5588. (https://doi.org/10.1093/hmg/ddv290)

Pepling ME \& Spradling AC 2001 Mouse ovarian germ cell cysts undergo programmed breakdown to form primordial follicles. Developmental Biology 234 339-351. (https://doi.org/10.1006/dbio.2001.0269)

Quill TA, Sugden SA, Rossi KL, Doolittle LK, Hammer RE \& Garbers DL 2003 Hyperactivated sperm motility driven by CatSper2 is required for fertilization. PNAS 100 14869-14874. (https://doi.org/10.1073/ pnas.2136654100)

Ramasamy R, Bakircioglu ME, Cengiz C, Karaca E, Scovell J, Jhangiani SN, Akdemir ZC, Bainbridge M, Yu Y, Huff C et al. 2015 Whole-exome sequencing identifies novel homozygous mutation in NPAS2 in family with nonobstructive azoospermia. Fertility and Sterility 104 286-291. (https://doi.org/10.1016/j.fertnstert.2015.04.001)

Reijo R, Lee TY, Salo P, Alagappan R, Brown LG, Rosenberg M, Rozen S, Jaffe T, Straus D, Hovatta O et al. 1995 Diverse spermatogenic defects in humans caused by $\mathrm{Y}$ chromosome deletions encompassing a novel RNA-binding protein gene. Nature Genetics 10 383-393. (https://doi. org/10.1038/ng0895-383)

Ren D, Navarro B, Perez G, Jackson AC, Hsu S, Shi Q, Tilly JL \& Clapham DE 2001 A sperm ion channel required for sperm motility and male fertility. Nature 413 603-609. (https://doi.org/10.1038/35098027)

Ruggiu M, Speed R, Taggart M, McKay SJ, Kilanowski F, Saunders P, Dorin J \& Cooke HJ 1997 The mouse Dazla gene encodes a cytoplasmic protein essential for gametogenesis. Nature 389 73-77. (https://doi. org/10.1038/37987)

Ryu, BY, Kubota H, Avarbock MR \& Brinster RL 2005 Conservation of spermatogonial stem cell self-renewal signaling between mouse and rat. PNAS 102 14302-14307. (https://doi.org/10.1073/pnas.0506970102)

Saragusty J, Diecke S, Drukker M, Durrant B, Friedrich Ben-Nun I, Galli C, Goritz F, Hayashi K, Hermes R, Holtze S et al. 2016 Rewinding 
the process of mammalian extinction. Zoo Biology 35 280-292. (https:// doi.org/10.1002/zoo.21284)

Sasaki H \& Matsui Y 2008 Epigenetic events in mammalian germ-cell development: reprogramming and beyond. Nature Reviews Genetics 9 129-140. (https://doi.org/10.1038/nrg2295)

Sasaki K, Yokobayashi S, Nakamura T, Okamoto I, Yabuta Y, Kurimoto K, Ohta H, Moritoki Y, Iwatani C, Tsuchiya H et al. 2015 Robust in vitro induction of human germ cell fate from pluripotent stem cells. Cell Stem Cell 17 178-194. (https://doi.org/10.1016/j.stem.2015.06.014)

Sato H, Miyamoto T, Yogev L, Namiki M, Koh E, Hayashi H, Sasaki Y, Ishikawa M, Lamb DJ, Matsumoto $\mathbf{N}$ et al. 2006 Polymorphic alleles of the human MEI1 gene are associated with human azoospermia by meiotic arrest. Journal of Human Genetics 51 533-540. (https://doi. org/10.1007/s10038-006-0394-5)

Sato T, Katagiri K, Gohbara A, Inoue K, Ogonuki N, Ogura A, Kubota Y \& Ogawa T 2011a In vitro production of functional sperm in cultured neonatal mouse testes. Nature 471 504-507. (https://doi.org/10.1038/ nature09850)

Sato T, Katagiri K, Yokonishi T, Kubota Y, Inoue K, Ogonuki N, Matoba S, Ogura A \& Ogawa T 2011b In vitro production of fertile sperm from murine spermatogonial stem cell lines. Nature Communications 2472. (https://doi.org/10.1038/ncomms1478)

Sato T, Yokonishi T, Komeya M, Katagiri K, Kubota Y, Matoba S, Ogonuki N, Ogura A, Yoshida S \& Ogawa T 2012 Testis tissue explantation cures spermatogenic failure in c-Kit ligand mutant mice. PNAS 109 16934-16938. (https://doi.org/10.1073/pnas.1211845109)

Sato T, Katagiri K, Kojima K, Komeya M, Yao M \& Ogawa T 2015 In Vitro Spermatogenesis in Explanted Adult Mouse Testis Tissues. PLOS ONE 10 e0130171. (https://doi.org/10.1371/journal.pone.0130171)

Seki Y, Hayashi K, Itoh K, Mizugaki M, Saitou M \& Matsui Y 2005 Extensive and orderly reprogramming of genome-wide chromatin modifications associated with specification and early development of germ cells in mice. Developmental Biology 278 440-458. (https://doi.org/10.1016/j. ydbio.2004.11.025)

Steinberger A \& Steinberger E 1967 Factors affecting spermatogenesis in organ cultures of mammalian testes. Journal of Reproduction and Fertility Supplement 2 117-124.

Steinberger A, Steinberger E \& Perloff WH 1964a Mammalian testes in organ culture. Experimental Cell Research 36 19-27. (https://doi. org/10.1016/0014-4827(64)90156-9)

Steinberger E, Steinberger A \& Perloff WH 1964b Initiation of spermatogenesis in vitro. Endocrinology 74 788-792. (https://doi. org/10.1210/endo-74-5-788)

Stouffs K, Vandermaelen D, Tournaye H, Liebaers I \& Lissens W 2011 Mutation analysis of three genes in patients with maturation arrest of spermatogenesis and couples with recurrent miscarriages. Reproductive BioMedicine Online 22 65-71. (https://doi.org/10.1016/j. rbmo.2010.08.004)

Suzuki H, Ahn HW, Chu T, Bowden W, Gassei K, Orwig K \& Rajkovic A 2012 SOHLH1 and SOHLH2 coordinate spermatogonial differentiation. Developmental Biology $361301-312 . \quad$ (https://doi.org/10.1016/j. ydbio.2011.10.027)

Tang WW, Dietmann S, Irie N, Leitch HG, Floros VI, Bradshaw CR, Hackett JA, Chinnery PF \& Surani MA 2015 A unique gene regulatory network resets the human germline epigenome for development. Cell 161 1453-1467. (https://doi.org/10.1016/j.cell.2015.04.053)

Tenenbaum-Rakover $\mathrm{Y}$, Weinberg-Shukron A, Renbaum P, Lobel $\mathrm{O}$, Eideh H, Gulsuner S, Dahary D, Abu-Rayyan A, Kanaan M, LevyLahad E et al. 2015 Minichromosome maintenance complex component 8 (MCM8) gene mutations result in primary gonadal failure. Journal of Medical Genetics 52 391-399. (https://doi.org/10.1136/ jmedgenet-2014-102921)

Tsuda M, Sasaoka Y, Kiso M, Abe K, Haraguchi S, Kobayashi S \& Saga Y 2003 Conserved role of nanos proteins in germ cell development. Science 301 1239-1241. (https://doi.org/10.1126/science.1085222)

Tung JY, Rosen MP, Nelson LM, Turek PJ, Witte JS, Cramer DW, Cedars MI \& Reijo-Pera RA 2006 Novel missense mutations of the Deleted-in-AZoospermia-Like (DAZL) gene in infertile women and men. Reproductive Biology and Endocrinology 4 40. (https://doi. org/10.1186/1477-7827-4-40)

Ueda T, Abe K, Miura A, Yuzuriha M, Zubair M, Noguchi M, Niwa K, Kawase Y, Kono T, Matsuda Y et al. 2000 The paternal methylation imprint of the mouse $\mathrm{H} 19$ locus is acquired in the gonocyte stage during foetal testis development. Genes to Cells 5 649-659. (https://doi. org/10.1046/j.1365-2443.2000.00351.x)

van Pelt AM, Roepers-Gajadien HL, Gademan IS, Creemers LB, de Rooij DG \& van Dissel-Emiliani FM 2002 Establishment of cell lines with rat spermatogonial stem cell characteristics. Endocrinology 143 1845-1850. (https://doi.org/10.1210/endo.143.5.8806)

Vogt PH, Edelmann A, Kirsch S, Henegariu O, Hirschmann P, Kiesewetter F, Kohn FM, Schill WB, Farah S, Ramos C et al. 1996 Human Y chromosome azoospermia factors (AZF) mapped to different subregions in Yq11. Human Molecular Genetics 5 933-943. (https://doi.org/10.1093/hmg/5.7.933)

Wu Y, Zhou H, Fan X, Zhang Y, Zhang M, Wang Y, Xie Z, Bai M, Yin Q, Liang D et al. 2015 Correction of a genetic disease by CRISPR-Cas9mediated gene editing in mouse spermatogonial stem cells. Cell Research 25 67-79. (https://doi.org/10.1038/cr.2014.160)

Xiao N, Kam C, Shen C, Jin W, Wang J, Lee KM, Jiang L \& Xia J 2009 PICK1 deficiency causes male infertility in mice by disrupting acrosome formation. Journal of Clinical Investigation 119 802-812. (https://doi. org/10.1172/JCl36230)

Yan W, Si Y, Slaymaker S, Li J, Zheng H, Young DL, Aslanian A, Saunders L, Verdin E \& Charo IF 2010 Zmynd15 encodes a histone deacetylasedependent transcriptional repressor essential for spermiogenesis and male fertility. Journal of Biological Chemistry 285 31418-31426. (https://doi.org/10.1074/jbc.M110.116418)

Yang F, Eckardt S, Leu NA, McLaughlin KJ \& Wang PJ 2008a Mouse TEX15 is essential for DNA double-strand break repair and chromosomal synapsis during male meiosis. Journal of Cell Biology 180 673-679. (https://doi.org/10.1083/jcb.200709057)

Yang F, Gell K, van der Heijden GW, Eckardt S, Leu NA, Page DC, Benavente R, Her C, Hoog C, McLaughlin KJ et al. 2008b Meiotic failure in male mice lacking an X-linked factor. Genes and Development 22 682-691. (https://doi.org/10.1101/gad.1613608)

Yatsenko AN, Georgiadis AP, Ropke A, Berman AJ, Jaffe T, Olszewska M, Westernstroer B, Sanfilippo J, Kurpisz M, Rajkovic A et al. 2015 X-linked TEX11 mutations, meiotic arrest, and azoospermia in infertile men. New England Journal of Medicine 372 2097-2107. (https://doi.org/10.1056/ NEJMoa1406192)

Ying QL, Nichols J, Chambers I \& Smith A 2003 BMP induction of Id proteins suppresses differentiation and sustains embryonic stem cell self-renewal in collaboration with STAT3. Cell 115 281-292. (https://doi. org/10.1016/S0092-8674(03)00847-X)

Yokonishi T, Sato T, Komeya M, Katagiri K, Kubota Y, Nakabayashi K, Hata K, Inoue K, Ogonuki N, Ogura A et al. 2014 Offspring production with sperm grown in vitro from cryopreserved testis tissues. Nature Communications 54320.

Yu XW Wei ZT Jiang YT \& Zhang SL 2015 Y chromosome azoospermia factor region microdeletions and transmission characteristics in azoospermic and severe oligozoospermic patients. International Journal of Clinical and Experimental Medicine 8 14634-14646.

Yuan L, Liu JG, Zhao J, Brundell E, Daneholt B \& Hoog C 2000 The murine SCP3 gene is required for synaptonemal complex assembly, chromosome synapsis, and male fertility. Molecular Cell 5 73-83. (https://doi.org/10.1016/S1097-2765(00)80404-9)

Zhang W, Zhang S, Xiao C, Yang Y \& Zhoucun A 2007 Mutation screening of the FKBP6 gene and its association study with spermatogenic impairment in idiopathic infertile men. Reproduction 133 511-516. (https://doi.org/10.1530/REP-06-0125)

Zhang HQ, Zhang XF, Zhang LJ, Chao HH, Pan B, Feng YM, Li L, Sun XF \& Shen W 2012 Fetal exposure to bisphenol A affects the primordial follicle formation by inhibiting the meiotic progression of oocytes. Molecular Biology Reports 39 5651-5657. (https://doi.org/10.1007/ s11033-011-1372-3)

Zhou Q, Wang M, Yuan Y, Wang X, Fu R, Wan H, Xie M, Liu M, Guo X, Zheng Y et al. 2016 Complete Meiosis from Embryonic Stem CellDerived Germ Cells In Vitro. Cell Stem Cell 18 330-340. (https://doi. org/10.1016/j.stem.2016.01.017)

Received 31 August 2017

First decision 28 September 2017

Revised manuscript received 24 October 2017

Accepted 13 November 2017 